\title{
DOS PINTURAS CON EL TEMA DE NUESTRA SEÑORA DEL ROSARIO
}

JosÉ Guadalupe Victoria

La llegada de pintores europeos a la Nueva España, especialmente flamencos y españoles, a partir de la séptima década del siglo xvI, fue fundamental para el ulterior desarrollo artístico en el virreinato. Simón Pereyns y Andrés de la Concha fueron los primeros grandes artífices que sentaron las base de una tradición pictórica de altos vuelos cuya influencia está fuera de toda duda. ${ }^{1}$

La importancia de estos artistas estriba, entre otras cosas, en el hecho de haber iniciado y fijado una iconografía que, en términos generales, pensamos, debido a la escasez de pintores que había en ese momento y a la gran demanda de pinturas, lo que les permitió satisfacer los constantes requerimientos artísticos durante el último tercio del siglo xvI.

En el estudio citado consignamos las principales obras realizadas por el segundo de esos artistas; entre las cuales ocupan un lugar importante las dos pinturas objeto de este artículo. Ahora bien, hace algunos años escribimos un artículo acerca de Concha; ahí consignamos sus datos biográficos, así como las obras de que se tiene noticia por referencia documental, o bien porque han llegado hasta nosotros. ${ }^{2}$ Ahí mismo expresamos nuestra opinión con referencia a la hipótesis de Martha Fernández, en el sentido de que hubieran existido dos artistas con el mismo nombre: un pintor que habría trabajado entre 1570-75 y 1599, y un arquitecto —quizá hijo de aquel一, cuyos trabajos pueden fecharse entre 1597 y $1611 .^{3}$ No es el caso repetir nuestros argumentos al respecto, simplemente reiteramos que se trata del mismo artista; por consiguiente, autor de las obras que estamos estudiando. ${ }^{4}$

\footnotetext{
${ }^{1}$ Guadalupe Victoria Vicencio, Les problèmes de la peinture en Nouvelle-Espagne entre la renaissance et le baroque. 1555-1625, París, Université de París X (Nanterre), 1982. Thèse de Doctorat de $3^{e m e ̀} C y c l e$. Vid también la versión española. Pintura y Sociedad en Nueva España. Siglo $X V I$. En prensa. Es obvio que antes de la llegada de estos dos pintores, hubo otros que pasaron al virreinato, pero su obra no tuvo la trascendencia de la de Pereyns y Concha, primero, y más tarde de la de Echave Orio; tal como hemos tratado de probar en nuestro estudio.

2 José Guadalupe Victoria, "Sobre las nuevas consideraciones en torno a Andrés de la Concha", Anales del Instituto de Investigaciones Estéticas, n. 50, v. I, p p. 76-86, México, 1982.

${ }^{3}$ Martha Raquel Fernández García, Maestros mayores de arquitectura en la ciudad de México en el siglo XVII (Estudio documental), México, UNAM, Facultad de Filosofia y Letras, 1981. Tesis de Maestría en Historia del Arte, p p. 70-88.

${ }^{4}$ Posteriormente la misma Martha Fernández escribió otro artículo en el que vuelve a insistir
} 
Otro punto de diferencia es el que se refiere al nombre del artista: mientras la historiografía tradicional -Toussaint y Angulo, especialmente- lo denomina Andrés de la Concha, autores como Enrique Marco Dorta y Martha Fernández prefieren llamarlo Andrés de Concha. Es cierto que en los documentos se le llama Andrés de Concha; pero creemos que la tradición historiográfica también tiene cierto peso y en nada altera que se le designe de una u otra manera. Además, porque según señalábamos en nuestro artículo de 1982, "los problemas que restan por resolver en cuanto a Concha, están más en relación con su obra en sí que con su vida". 5

Pues bien, sin perder de vista esta idea, nuestras investigaciones acerca de la pintura novohispana del último tercio del siglo xvi nos han llevado a estudiar dos obras cuyo interés estriba no sólo en su excelente calidad pictórica sino, sobre todo, en la iconografía representada. Aspecto este último que trataremos enseguida.

Una de éstas forma parte del retablo de Yanhuitlán, Oax., (fig. 1) que, como se sabe, originalmente fue realizada hacia $1575 .^{6}$ La estructura fue cambiada en la época barroca conservándose únicamente las pinturas del siglo xvi, integradas al nuevo retablo. La otra pintura se conserva en la iglesia dominica de Tláhuac, D.F., (fig. 2) donde, al parecer, siempre ha estado. Sin embargo, hace poco tiempo pudo compararse con la del retablo de Yanhuitlán y, en consecuencia, atribuirla al maestro Concha. ${ }^{7}$

Ambas obras fueron realizadas con técnica al óleo sobre tabla; desgraciadamente no ha sido posible medirlas debido al sitio en que se encuentran colocadas. Tampoco hemos podido obtener noticias acerca del momento en que fueron realizadas, ni por encargo de quién. Suponemos que la del retablo de Yanhuitlán —si efectivamente perteneció al antiguo conjunto- formaba parte de un programa iconográfico que hoy

sobre la posibilidad de que hayan existido dos artistas con el mismo nombre. Vid. "El Matrimonio de Andrés de Concha". Anales del Instituto de Investigaciones Estéticas, n. 52, México, 1983, p p. 85-99. Guillermo Tovar de Teresa, a su vez, no ha mucho tiempo publicó una nota en la que, pese a la falta de rigor científico, señala que los documentos de la época muestran que se trata de un solo artista. "Andrés de la Concha . El rescate de un artista del siglo XVI" Excelsior, jueves 17 de enero de 1985.

${ }^{5}$ José Guadalupe Victoria, op cit., p. 86

"Manuel Toussaint, "Notas sobre Andrés de la Concha" Revista Mexicana de Estudios Históricos, $\mathrm{t} . \mathrm{I}, \mathrm{n} .1$, enero-febrero de 1927.

${ }^{7}$ La pintura era conocida por todos desde tiempo atrás; gracias a los trabajos de restauración llevados a cabo en el templo pudo admirarse con mayor detenimiento. Sin embargo, el primero en publicar la atribución a Concha fue Guillermo Tovar de Teresa, Pintura y escultura del renacimiento en México, México, INAH, 1979, p p. 135, 136, 235, 397; figs. 112-114 
en día estamos lejos de imaginar. A decir verdad, por las pinturas que se conservan-y que con toda razón fueron atribuídas a la paleta de Concha por Manuel Toussaint, desde 1927- no es factible pensar que la pintura de Nuestra Señora del Rosario haya formado parte del programa del antiguo retablo. Lo que por otra parte no invalida su antigüedad e incluso contemporaneidad respecto a dicha obra. Cabría suponer, entonces, que fue realizada para otro conjunto, o bien como obra independiente que andando el tiempo - al cambiarse la estructura dieciseisena por otra barroca - se decidiera integrarla ahí, dada su excelente calidad y, sobre todo, la devoción que representaba tanto para los fieles como para la orden guardiana del convento.

La tabla de Tláhuac también es posible que haya sido realizada como obra independiente; aunque no excluímos el hecho de que formara parte de un retablo hoy en día desaparecido. Como quiera que sea, salta a la vista el parentesco tan marcado entre ambas; casi podría decirse que son iguales en todos los aspectos pero, sin duda alguna, la semejanza mayor radica en su iconografía.

¿Se trata efectivamente de una representación de Nuestra Señora del Rosario? Y de ser así, ¿cuáles fueron sus fuentes gráficas y literarias?

Vayamos un poco hacia atrás. La devoción al rosatio y a la Virgen como intercesora a través de él, se debe a los dominicos. La devoción, parece innecesario repetirlo aquí, tuvo su origen en Europa; y en España alcanzó un desarrollo inusitado.

A1 pasar la Orden de Predicadores a la Nueva España trajo ese culto y lo promovió entre la población nativa, desde fecha temprana. Según el cronista Dávila Padilla, fue fray Domingo de Betanzos el primero en impulsar tal devoción. Sin embargo sus empeños fueron superados por fray Tomás de San Juan pues a este religioso, en una ocasión, estando enfermo, se le apareció el demonio, viéndose en la necesidad de invocar a la Virgen, quien le tendió la mano y le indicó: "no temas, hijo fray Tomás, que contigo estoy; levántate y predica mi Rosario, que yo te favoreceré". ${ }^{9}$ Una vez aliviado el religioso solicitó al prior de su convento que le permitiera fundar la Cofradía del Santísimo Rosario, logrando sus propósitos posteriormente.

La fundación pues de una cofradía del rosario confirmaba una costumbre que existía prácticamente desde el establecimiento de la Orden

\footnotetext{
${ }^{8}$ Manuel Toussaint, op cit.

${ }^{9}$ Fray Agustín Dávila Padilla, Historia de la fundación.... , p p. 48, 81, 408-412, 502, 532, 541542 , y $613-618$
} 
en el virreinato. Así permiten afirmarlo, por una parte, las numerosas obras que se publicaron durante el siglo Xvi, relacionadas con la devociôn del rosario. Por otra parte las imágenes — sobre todo grabadosrepresentando a la Virgen del Rosario circularon en grado sumo.

Es posible pensar que el maestro Concha haya conocido tanto la literatura rosariana como las imágenes de la Virgen, bajo esa advocación, y que en ella se haya inspirado para tealizar sus obras.

Una de las primeras imágenes de la Virgen del Rosario que se conocieron en Nueva España es un grabado de 1565 (fig. 3). En él puede verse a la virgen con el Niño, sobre un altar; frente a ella hay varios personajes entre los que se distingue un grupo de religiosos encabezados por un papa, en el extremo izquierdo; al centro se ve un personaje masculino, arrodillado, que a primera vista parece un indígena, y en el ángulo derecho puede observarse a un personaje - iun guerrero?en actitud de desenvainar una espada ${ }^{10}$ Los rasgos que debemos destacar de esta iconografía son dos, esencialmente: los rosarios que sostienen los orantes y la corona de rosas que sostiene el Niño entre stis manos y que deja caer hacia la figura central. También debe tomarse en cuenta la inscripción que recorre la arquivolta del arco que enmarca la composición; la cual desgraciadamente - debido al tamaño del grabado- no es fácil de leer.

Posterior a este grabado es el que imprimió Pedro Ocharte en $1571 .^{11}$ $\mathrm{Su}$ autor fue Juan Ortiz y por el hecho de haber incluido unos versos en la estampa, la Inquisición le siguió un proceso; gracias a lo cual conocemos la imagen. La infortunada relación de Ortiz con el tribunal de la $\mathrm{Fe}$ ha sido tratada por Edmundo O'Gorman; ${ }^{12}$ aquí hemos de ceñirnos a resaltar las particularidades iconográficas de la estampa.

Según puede observarse en la ilustración (fig. 4) aparece la Virgen con el Niño sobre una media luna y, alrededor puede verse un sinnúmero de rayos. No está por demás señalar que este tipo de imagen fue muy frecuente en España y, gracias a la difusión de las estampas, se conoció y copió allende el océano.

En los ángulos superiores aparecen sendos ángeles que portan rosarios y varas de azucena. Su colocación recuerda las imágenes angélicas

\footnotetext{
${ }^{10}$ El grabado fue reproducido por Manuel Romero de Terreros. Véase: Grabados y grabadores en la Nueva España, lám. 31. Desgraciadamente el autor no proporciona la fuente de donde proviene el grabado

"Edmundo O'Gorman, "An Early Mexican Xylograph Incunabula". Mexican Art and Life, n 7, p. 16-19. México, julio de 1939.

${ }^{12}$ Ibidem
} 


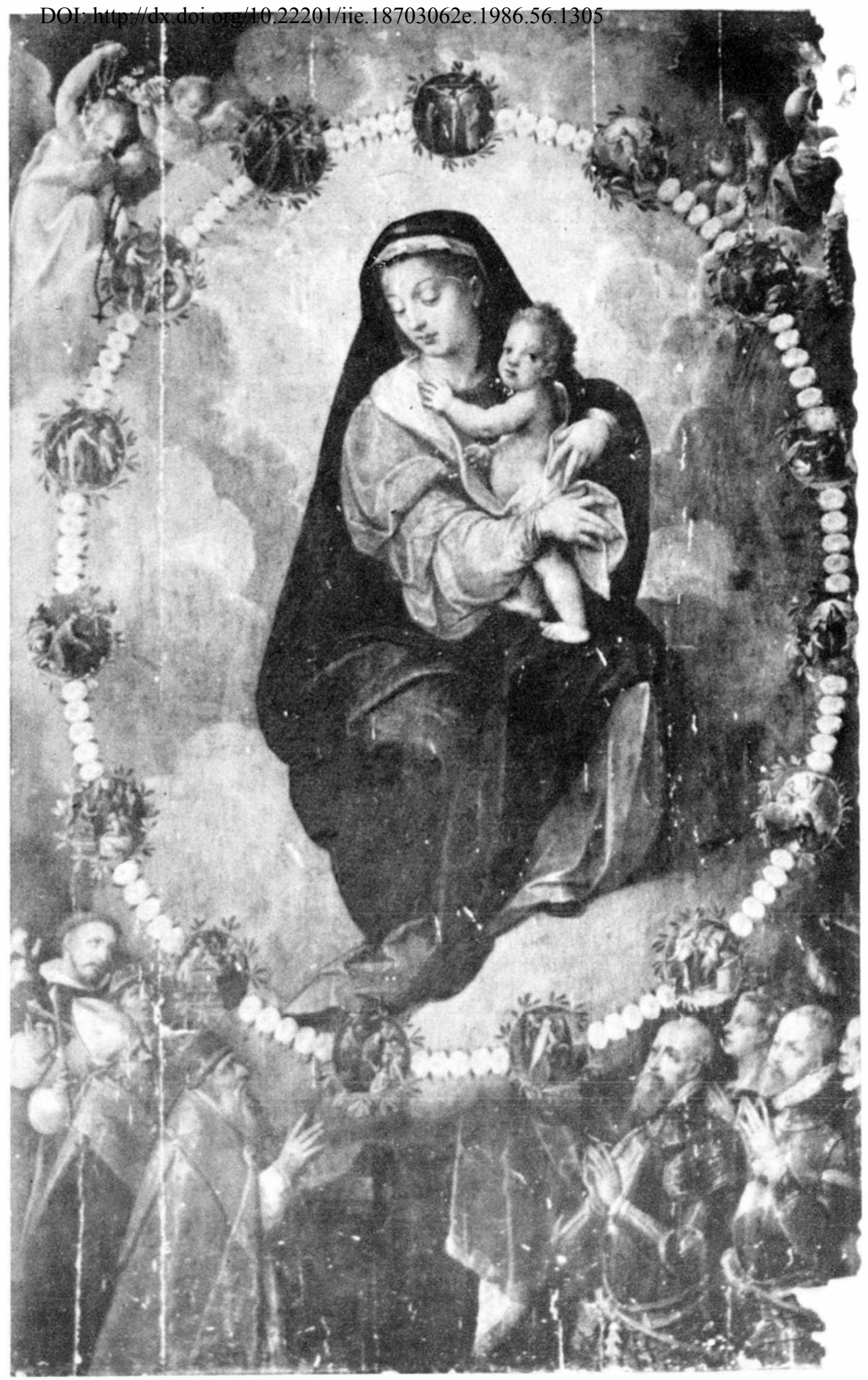

Figura 1. Andrés de la Concha (atrib.). Nuestra Señora del Rosario. Retablo de Yanhuitlán, Oax. 


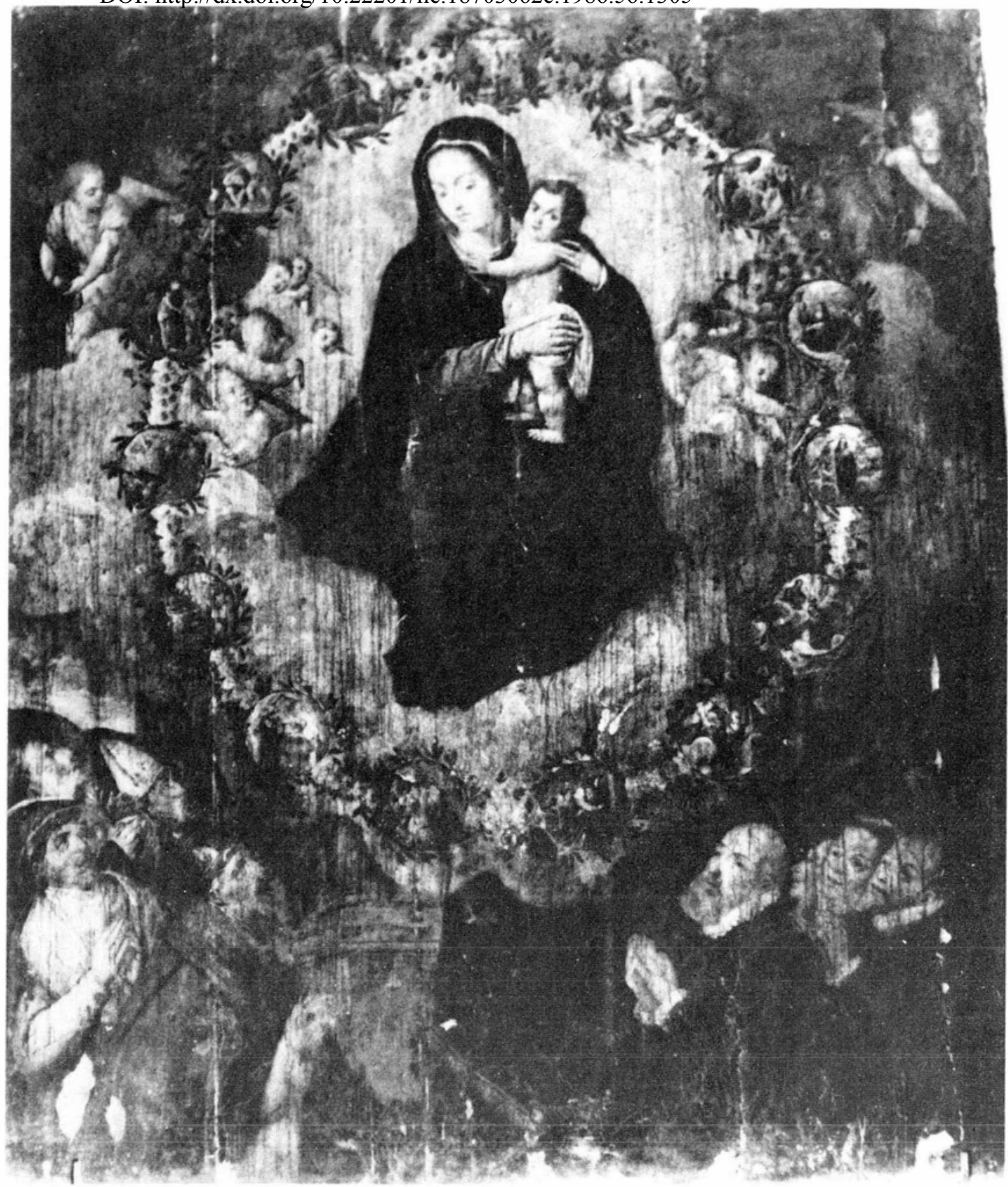

Figura 2. Andrés de la Concha (atrib.). Nuestra Señora del Rosario. Parroquia de Tláhuac, D. F. 


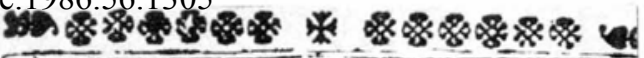

Figura 3. Virgen del Rosario, 1565.

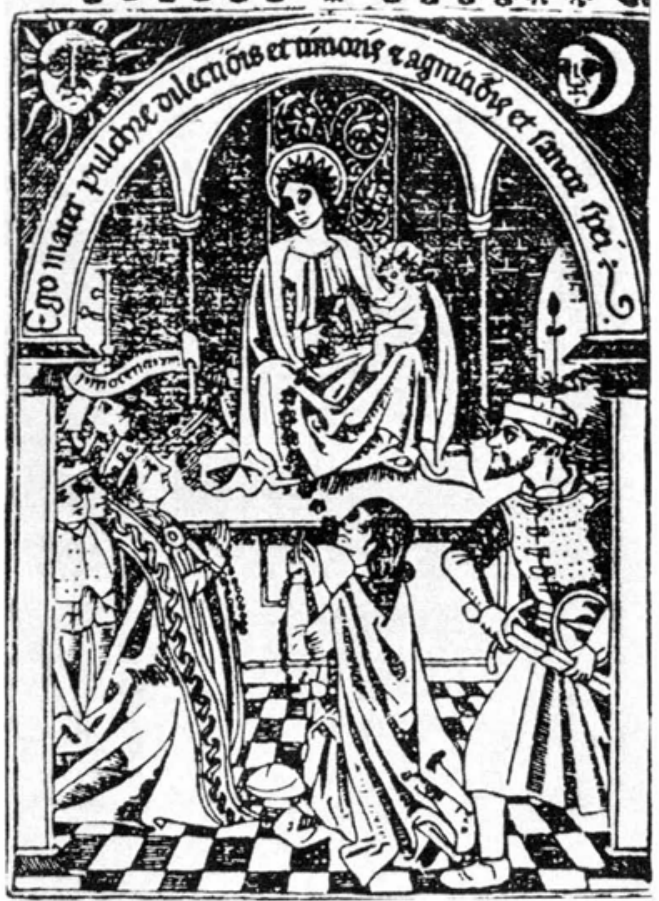

Figura 4. Virgen del Rosario. Grabado de Juan Ortiz. México, 1571.

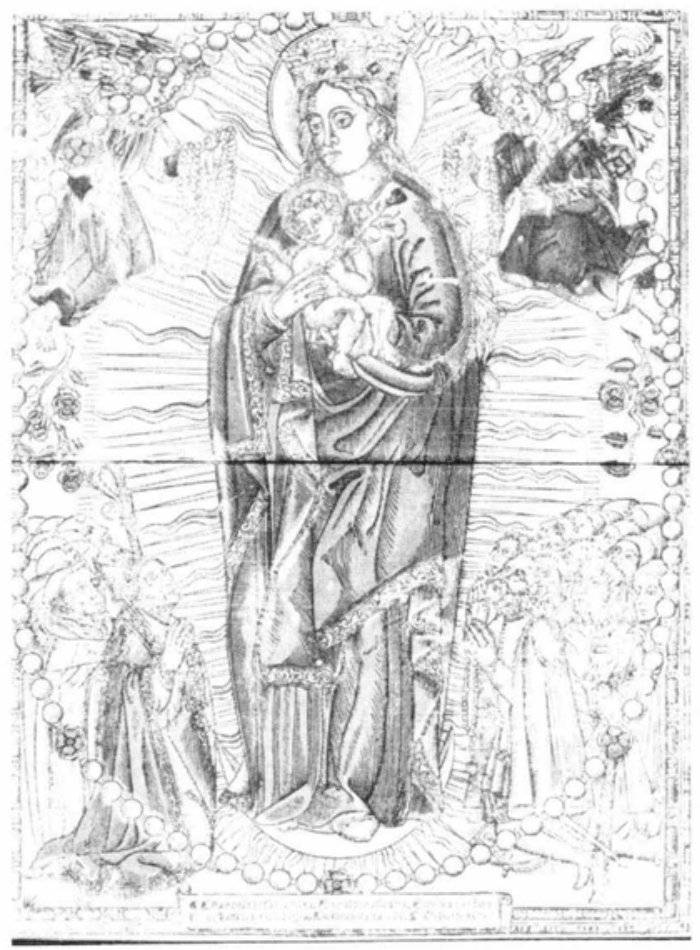




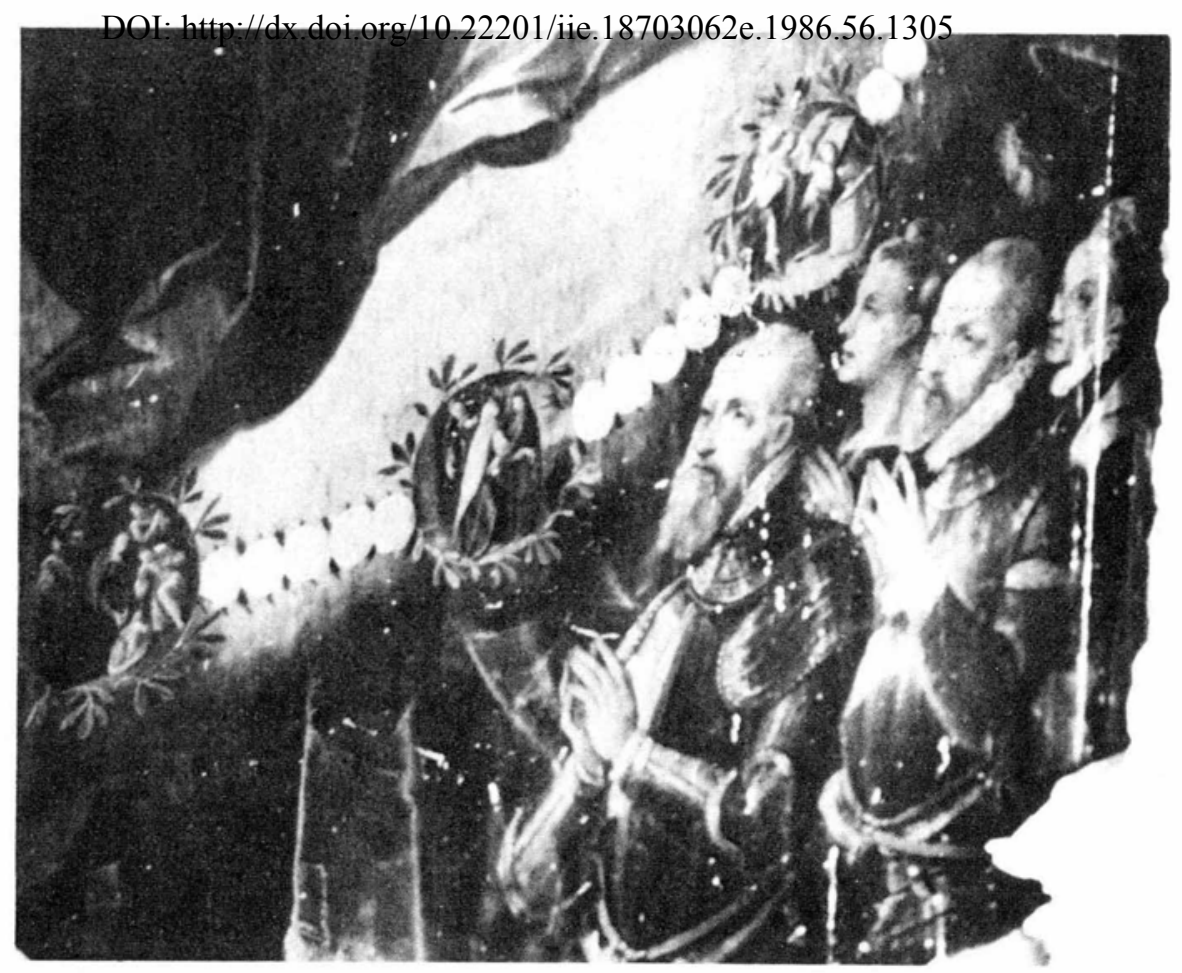

Figura 5. Andrés de la Concha (atrib.). Nuestra Señora del Rosario (pormenor). Retablo de Yanhuitlán, Oax.

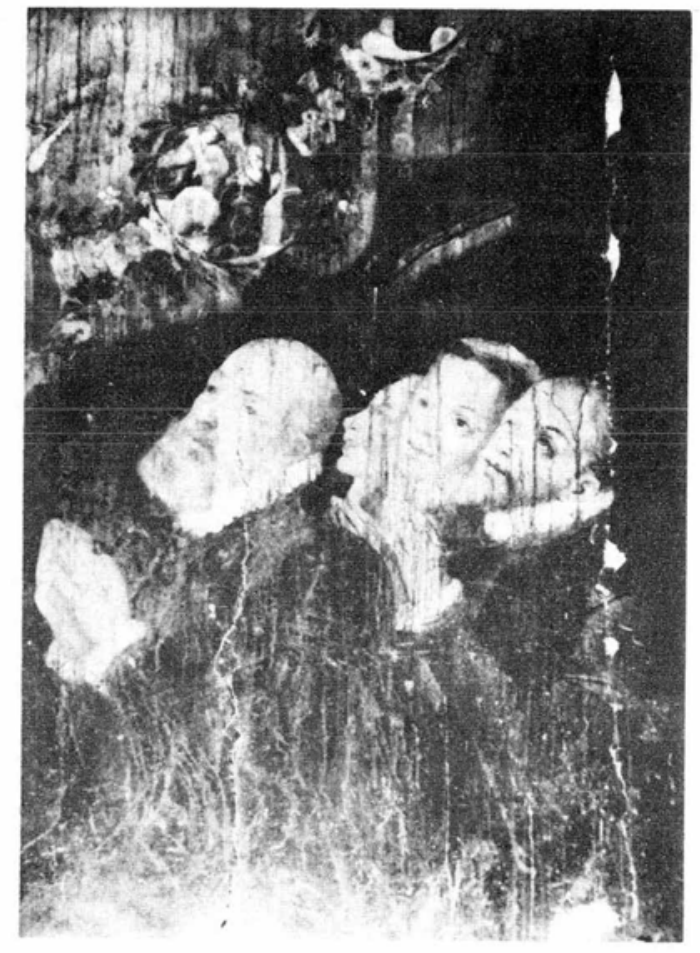

Figura 6. Andrés de la Concha (atrib.). Nuestra Señora del Rosario (pormenor). Parroquia de Tláhuac, D. F. 
de filiación flamenca que abundaron en la época y que también fueron reproducidas por algunos pintores novohispanos, verbigracia por Pereyns en su llamada Virgen del Perdón. ${ }^{13}$

En, contrapartida a estos ángeles vemos, en la parte inferior, dos grupos de personajes; en el de la izquierda, predominan los religiosos encabezados por un obispo y un fraile, en actitud orante; el primero de ellos junta las manos y sostiene un rosario.

En el grupo de la derecha están representados varios personajes laicos - también en actitud orante-, distinguiéndose casi perfectamente los cuatro primeros. El que los encabeza es un recio hombre español, vestido a la usanza de la época, con capa y gola entre otras prendas; a su derecha apenas puede apreciarse la figura de una mujer. Detrás de él hay otro personaje barbado, también vestido a la moda española $y$, sin embargo, visto con cuidado no puede menos que pensarse que tal vez represente a un indígena; en lugar de capa parece lucir una tilma. Los personajes colocados en la parte posterior son menos fáciles de indentificar.

Otra particularidad iconográfica de esta estampa es el rosario cuyas suentas están agrupadas en número de diez, separadas por una flor de cuatro pétalos. En los extremos del cuadro y más como recursos decorativo que iconográfico aparecen ramas con flores.

El interés de los dos grabados, para el tema que estamos estudiando, es capital pues permite suponer que para esa época ya existía una iconografía de la Virgen del Rosario en donde el elemento fundamental es, precisamente, un rosario, independiente del modo como éste fuera representado. Pero, más importante aún es la inclusión de personajes

\footnotetext{
${ }^{13}$ Manuel Toussaint, Pintura Colonial en México, p. 61 . De esta singular manera de representar los misterios del Rosario conocemos otro ejemplo, aunque no lo hemos podido estudiar directamente; el cual se localiza en la iglesia dominica de Cuilapan, Oax. Se trata de un nicho de un retablo atribuído a Andrés de Concha. Las fotografías que hemos consultado - mismas que pertenecen al Archivo Fotográfico del Instituto de Investigaciones Estéticas de la UNAM - muestran un trabajo de talla y escultura de fines del siglo xvi o principios del siglo XVII. Sin embargo, lo más importante son las pinturas, en forma de medallones, que rodean el nicho, realizadas al óleo sobre tabla. Representan los quince misterios del Rosario de manera similar a como están representados en las tablas de Yanhuitlán y de Tláhuac. Tal similitud rebasa el ámbito formal pues vistas con detenimiento se cae en la cuenta de que las diver sas escenas están inspiradas en los mismos modelos grabados que Concha manejó en los lienzos grandes de los retablos de Yanhuitlán y de Coixtlahuaca; por ejemplo el tipo de madona de rasgos faciales muy fínos y cuello largo, o el tipo de Cristo desnudo en escenas como la de La Ascención.

La singularidad de esta obra, desde el punto de vista pictórico e inconográfico, amerita un estudio más detallado que por el momento no nos es posible realizar. Esper amos llevarlo a cabo en un futuro próximo.
} 
-religiosos y laicos - dentro de una composición. Práctica usual en la península, por fuerza había de manifestarse en la Nueva España.

El avisado lector se habrá percatado que hemos hecho a un lado un aspecto fundamental: ¿quiénes son los personajes representados? Dejaremos un intento de respuesta para más adelante y por el momento nos ceñiremos a señalar que ambas estampas pudieron ser los antecedentes gráficos manejados por Concha para la realización de sus pinturas.

En la tabla de Yanhuitlán la Virgen ocupa casi la totalidad del cuadro, aparece sentada con el Niño de pie entre sus brazos, en un trasfondo de nubes. Alrededor de la madre de Dios se ve el rosario de rosas repartidas en grupos de cinco y separadas por medallones en los que aparecen escenas alusivas a los misterios del rosario.

En los ángulos superiores del lienzo se ven sendos pares de angelillos que portan rosarios -rojos y negros - y coronas de rosas.

La parte baja del lienzo la ocupan dos grupos de personajes, al parecer de pie, en actitud orante. El grupo de la izquierda está constituído por cuatro personajes religiosos: un papa, un obispo, un cardenal y un fraile dominico. ¿Quiénes son estos personajes? ¿Se trata de personas reales o su representación simplemente alude a la jerarquía eclesiástica? EI tema amerita mayor detenimiento; así hemos de dar una respuesta a medias. El fraile dominico, creemos, representa a santo Domingo de Guzmán, fundador de la Orden de Predicadores y, además, según la tradición, impulsor del culto pues el santo "lo había recibido, de manos de la madre de Dios como el arma más eficaz contra la secta de los albigenses". ${ }^{14} \mathrm{El}$ cardenal aquí representado, pensamos, tiene que ser real; descartamos la posibilidad de que se trate de san Jerónimo pues no es esa la manera tradicional de representarlo. En cuanto al obispo no podemos ni queremos aventurar alguna hipótesis acerca de su identificación. En cambio el papa posiblemente represente a san Pío $\mathrm{V}$ quien, como se sabe, de alguna manera impulsó la devoción. ${ }^{15}$

El otro grupo está constituído también por cuatro personajes que, curiosamente, no han sido identificados por quienes han estudiado la obra de Concha (fig. 5). Se trata del emperador Carlos V, de su hijo el rey Felipe II, de la esposa del Emperador, Isabel de Portugal y de Isabel de Valois, tercera esposa del rey prudente.

${ }_{15}^{14}$ Enciclopedia de la Religión Católica, t, VI, p. 814.

${ }^{15}$ Ibidem. 
Estos personajes están representados de pie, en actitud orante, con las manos juntas. El emperador y su hijo visten traje militar; sus esposas van ataviadas a la usanza de la época. Detrás de ellos un cortinaje sirve de telón de fondo; a la vez que de separación entre la "imagen celestial" y la representación terrestre.

La composición de la pintura de Tláhuac, en términos generales, es la misma (fig. 6). Sin embargo cambian las actitudes de los ángeles en los extremos superiores; además de que Concha incluyó grupos de amorcillos dentro del círculo que describe el rosario, a los lados de la Virgen.

En los grupos de personajes de la parte baja también introdujo algunas novedades. Mantienen la actitud orante, aunque se nota el empeño del pintor por indicar que están de pie. El orden en que aparecen colocados los religiosos también varía; vemos al papa y a su lado al obispo, detrás de ellos aparecen el cardenal y el fraile dominico. Acerca de su identificación podemos señalar lo mismo que para los del cuadro de Yanhuitlán; si bien debemos insistir en que el cardenal quizá represente a un personaje histórico pues sus facciones están bien individualizadas.

Innovación de Concha para separar los grupos, fue la inclusión de un alto pedestal donde se deplanta una columna; además un cortinaje de tonalidad oscura sirve de fondo.

Los personajes reales son los mismos, aunque el emperador y su hijo don Felipe aparecen vestidos de civiles.

Estos cuadros de Concha, según se desprende de la descripción anterior, presentan varios aspectos que conviene resaltar. En cuanto a la iconografía de la Virgen queremos indicar que el artista empleó modelos de procedencia italiana, conocidos a través de obras o de grabados como el de la ilustración número tres. Esta iconografía está ligeramente disfrazada por la inclusión de figuras angélicas de filiación septentrional. El diseño del rosario también puede considerarse arcaizante pues vemos que se emparenta con modelos del siglo xv.

No obstante, a nuestro modo de ver, donde verdaderamente reside la novedad de estos cuadros - sin perder de vista que aludimos únicamente a la iconografía - es en el hecho de haber incluido sendos grupos de personajes en la parte baja de la composición. No es que Concha sea el primero en hacerlo; no, esa era una práctica corriente en la península. Pero en todo caso sí fue uno de los primeros en implantarla en el virreinato. Esto es muy importante pues no olvidemos que, junto con Pereyns, sentaron las bases de la tradición pictórica novohispana. 
Esta manera de representar 0 incluir personajes religiosos y laicos en composiciones de carácter sagrado puede inscribirse dentro del género de pintura con donante. ${ }^{16}$ Género que continuarían en el virreinato los pintores posteriores a Concha; siendo el más importante Baltasar de Echave Orio. ${ }^{17}$

Las obras de Concha se tornan mayormente significativas por el hecho de ser de las primeras dentro de la producción pictórica de la épooa donde aparecen "verdaderos y auténticos" retratos. Por si fuera poco se trata de efigies de los monarcas españoles.

Los retratos de la realeza española no abundan en Nueva España; a pesar dé que fue práctica corriente que los reyes enviaran retratos para ser colocados en el Palacio de los Virreyes y en otras dependencias gubernamentales. ${ }^{18}$ Algunas de esas obras eran de primera calidad: de Tiziano a Sánchez Coello, pasando por Antonio Moro y Pantoja de la Cruz. Pero desgraciadamente las obras que se han conservado son de escasa importancia artística.

Vistos en este contexto, los retratos pintados por Concha resultan excepcionales, aunque no es fácil saber en qué obras pudo inspirarse. Es un hecho de que no se trata totalmente de "versiones libres". Sin embargo, sería muy aventurado suponer que haya conocido a la familia real y tampoco estamos seguros de que haya visitado la corte, como tal parece que sí acurrió con Pereyns.

Al revisar la iconografía de los reyes españoles - sobre todo la que ha sido publicada - caemos en la cuenta del parecido que guardan las representaciones de Concha, con las hechas por otros artistas europeos. El emperador, por ejemplo, muestra un marcado prognatismo, así como una avanzada calvicie; rasgos que no fueron disimulados por sus retratistas.

El retrato de Carlos $\mathrm{V}$ pintado por Concha puede añadirse al grupo en que, según Sánchez Cantón, el emperador aparece "adulto, con pelo corto y barba"." 19 Añade el autor que "como era natural, esta moda se impuso a toda Europa. Suele suponerse nacida del deseo del Emperador de disimular su prognatismo". 20

\footnotetext{
${ }^{16}$ Para el caso de la pintura con donante en la Nueva España, véase: Elisa Vargas Lugo, "E1 retrato de donantes y el autorretrato en la pintura novohispana". Anales del Instituto de Investigaciones Estéticas, v. XXIII, n. 51, pp. 13-20, México, 1983.

${ }^{17}$ José Guadalupe Victoria "Los autorretratos de Baltazar de Echave Orio". Anales del Instituto de Investigaciones Estéticas, v, XIV, n. 53, pp. 75-79, México, 1983.

${ }^{18}$ Manuel Toussaint, op. cit., pp. 55-58.

${ }^{19} \mathrm{~F}$. J. Sánchez Cantón, Los retratos de los reyes españoles, p. 109

${ }^{20} \mathrm{Ibidem}$.
} 
Pero si en el caso del retrato de Carlos $\mathrm{V}$ resulta difícil imaginar cuál pudo ser la fuente donde se inspiró Concha, en el de la emperatriz prácticamente se torna un enigma. Hay que recordar, como indica el mismo Sánchez Cantón, que no son tantos los retratos que se hicieron a la soberana; los que se conocen son posteriores a su muerte, incluso los de Tiziano. Esto bastaría para afirmar que el pintado por Concha necesariamente está inspirado en una "versión libre".

Como quiera que sea y pese a la deficiente documentación gráfica con que contamos, los rasgos de la soberana coinciden con los representados tanto en el cuadro del Museo del Duque de Alba - publicado por Sánchez Cantón- como con el de Tiziano que conserva el Prado.

El retrato de Felipe II nos muestra a un hombre de mediana edad, rostro hermoso y mirada penetrante; aunque sin dejar de remarcar el prognatismo y la calvicie, como en el caso de su padre.

De la tercera esposa del rey prudente, Isabel de Valois, tampoco se conservan muchos retratos. Sánchez Cantón indica que fue retratada dos veces por Sánchez Coello, "en lienzos que llegaron a nosotros sólo mediante copias, excelentes, de su discípulo Juan Pantoja de la Cruz", 21 Tuvo fama de ser muy dada a la ostentación; y así parecen probarlo los cuadros conservados en el Museo del Prado y en el Kunsthistoriches Museum de Viena. Sin embargo, Concha nos dejó una imagen sobria de ella, quizá como correspondía al tipo de pintura piadosa que realizaba.

En cuanto a la calidad pictórica de estos retratos, podemos decir que es de primer orden. Excelente dibujo y magnífico colorido que van muy acorde con la totalidad de los lienzos, como que Concha era un artista sabedor de su oficio. Desgraciadamente el medio artístico del virreinato era muy pobre y los artífices habían de explotar los escasos medios de que disponían para la composición de sus obras. Decimos esto porque sin duda fue Concha uno de los que se sirvieron con mayor intensidad de un reducido número de grabados para realizar varias obras.

Precisamente por lo anterior es que destacan las representaciones de la familia real que incluyo en sus versiones de Nuestra Señora del Rosario. Retratos ciertamente de mayor interés pictórico e iconográfico que los que se conservan en algunos museos mexicanos. De ahí nuestro empeño en identificarlos y darlos a conocer a través de estas líneas. 